\title{
Digestibility of calcium and digestible calcium from inorganic sources evaluated in swine by two methods
}

\author{
Digestibilidade de cálcio e cálcio digestível de fontes inorgânicas avaliada em suínos \\ por dois métodos
}

SANTANA, Ana Lúcia Almeida ${ }^{1} *$; TEIXEIRA, Alexandre de Oliveira ${ }^{2}$; LOPES, Darci
Clementino , SANTANA, Rodrigo Almeida $^{3}$, ROCHA JUNIOR, Carlos Magno ${ }^{1}$;
MOREIRA, Leonardo Marmo $^{2}$; HANNAS, Melissa Izabel ${ }^{1}$; CORASSA, Anderson ${ }^{4}$

${ }^{1}$ Universidade Federal de Viçosa, Departamento de Zootecnia, Viçosa, Minas Gerais, Brasil.

${ }^{2}$ Universidade Federal de São João Del Rei, Departamento de Zootecnia, São João del-Rei, Minas Gerais, Brasil.

${ }^{3}$ Universidade Federal do Recôncavo da Bahia, Centro de Ciências Agrárias, Ambientais e Biológicas, Cruz das Almas, Bahia, Brasil.

${ }^{4}$ Universidade Federal do Mato Grosso, Departamento de Zootecnia, Sinop, Mato Grosso, Brasil.

*Endereço para correspondência: zootecana@gmail.com

\section{SUMMARY}

The objective of the study was to determine the digestible calcium from different sources by direct and indirect methods. Thirty castrated male pigs were used, distributed in randomized blocks, in six treatments: 1- Calcitic limestone; 2Dicalcium phosphate powder $18 \%$; 3- Dicalcium phosphate powder 20\%; 4- Dicalcium microgranulated phosphate $18 \%$; 5Monodicalcium microgranulated phosphate 20\%; 6- Monodicalcium microgranulated phosphate $21 \%$, with six replicates and one animal per experimental unit. A basal diet was formulated to meet the nutritional requirements of the animals, except for calcium $(0.06 \%)$ and the evaluated sources replaced the basal diet in order to provide $0.45 \%$ of total $\mathrm{Ca}$. At the same time, two stool collection methods were evaluated: total collection and fecal indicator. The animals were housed in metabolism cages for 12 days to collect feces and urine to determine the calcium values used to estimate digestibility coefficients and digestible calcium. The total collection method and the faecal indicator method did not affect the true digestibility coefficient of calcium. The calcium digestibility of the microgranulated dicalcium phosphate $21 \%$ (MM21) was superior in comparison with the other calcium sources evaluated by the indirect method in the present study. The average values of true digestibility of the calcium sources, in percentage, were: calcitic limestone: 82.47; dicalcium phosphate powder 18\%: 80.87; dicalcium phosphate powder $20 \%$ : 85.65 ; dicalcium microgranulated phosphate 18\%: 81.65; monodicalcium microgranulated phosphate 20\%: 84.15 ; and monodicalcium microgranulated phosphate $21 \%: 88.35$. The two methodologies can be used to determine the digestibility of calcium.

Keywords: absorption, mineral, solubility

\section{RESUMO}

Objetivou-se determinar o cálcio digestível de diferentes fontes pelos métodos direto $\mathrm{e}$ indireto. Foram utilizados 36 suínos machos castrados, distribuídos em blocos casualizados em seis tratamentos, sendo: 1- calcário calcítico, 2- fosfato bicálcico pó 18\%, 3- fosfato bicálcico pó $20 \%$, 4- fosfato bicálcico microgranulado $18 \%$, 5- fosfato monobicálcico microgranulado $20 \%$ e 6 - fosfato monobicálcico microgranulado $21 \%$, com seis repetições e um animal por unidade experimental. Uma ração basal foi formulada para atender as exigências nutricionais dos animais, exceto para cálcio $(0,06 \%)$ e as fontes avaliadas substituíram a ração basal de modo a fornecer $0,45 \%$ de $\mathrm{Ca}$ total. Foram avaliados ao mesmo tempo dois 
métodos de coleta de fezes: coleta total e indicador fecal. Os animais foram alojados em gaiolas de metabolismo por 12 dias para coleta de fezes e urina para determinação dos valores de cálcio, utilizados para estimar os coeficientes de digestibilidade e o cálcio digestível. Os métodos de coleta total e do indicador fecal não afetaram o coeficiente de digestibilidade verdadeiro do cálcio. A digestibilidade do cálcio no fosfato bicálcico microgranulado $21 \%$ (MM21) foi superior em comparação com as fontes de cálcio avaliadas pelo método indireto no presente estudo. Os valores médios da digestibilidade verdadeira das fontes de cálcio, em porcentagem, foram: calcário calcítico: 82,47 ; fosfato bicálcico em pó 18\%: 80,87; fosfato bicálcico em pó 20\%: 85,65; fosfato bicálcico microgranulado $18 \%$ : 81,65 ; fosfato monobicálcico microgranulado 20\%: 84,15 ; e fosfato monobicálcico microgranulado $21 \%$ : 88,35 . As duas metodologias podem ser empregadas para determinar a digestibilidade do cálcio.

Palavras-chave: absorção, minerais, solubilidade

\section{INTRODUÇÃO}

Calcium is essential to the living beings, and constitutes the mineral of greater concentration in the organisms. According to Araújo et al. (2008), minerals are considered essential elements for good animal nutrition, however, are not synthesized by the body and need to be supplied via diet, being natural foods of vegetable or animal origin the main source of this supplement. But, second Fiorini (2008) these foods do not always provide the quantity to meet the organic needs and are supplied above the requirements.

One of the problems in feeding pigs is related to the digestibility of minerals, because in the main ingredients of the diet, corn and soybean, many of them are complexed with phytic acid (SELLE et al., 2009), making it necessary to include some inorganic source in the feed. Among the sources that can be used in calcium supplementation are those from calcareous rocks (limestone and phosphates), the more often used in feed because they are found in greater abundance and are of low cost (SANTANA et al., 2017). However, the physical and chemical characteristics of the source may negatively affect the digestibility and consequently the availability of the mineral.

Some of the methods of fecal sampling have been used to determine the digestibility of food and nutrients, as the total sampling method and the fecal indicator method. The literature is scarce in studies concerning to the true digestibility of calcium sources used in the diet of pigs, probably due to the difficulty in determining the endogenous calcium. Important data from the literature provide (ROSTAGNO et al., 2017) the total calcium concentrations of the ingredients and calcium sources used in the feeding of non-ruminant animals, which can be associated to the greater inclusion of calcium sources in the ration. Nevertheless, if the calcium digestibility is not considered, the calcium: phosphorus relation can be significantly increased, decreasing, in this way, the digestibility of several nutrients of the diet.

From the values of the digestible calcium, its inclusion on feed may be reduced and the space that was previously occupied with calcium sources may be used for energy and or protein sources. Furthermore, these substitutions might minimize the environmental pollution caused by the excess of mineral in the excreta.

The objective of the present work was to determine the digestible calcium of several sources by the direct and indirect methodologies. 


\section{MATERIAL AND METHODS}

The experiment was conducted at the Pig Swine Sector of the Animal Science Department (Departamento de Zootecnia, DZO) of Universidade Federal de Viçosa (UFV), located in city of Viçosa, Minas Gerais state, Brazil. The experimental procedures were evaluated and approved by the Ethics Committee on the Use of Animals of the Animal Science Department of UFV, protocol no. 29/2011.

It was utilized 36 castrated males, with initial live weight of $30 \mathrm{~kg} \pm 2,8 \mathrm{~kg}$, distributed in completely randomized block design, in six treatments: 1- CAC: Calcitic limestone; 2- DP18: Dicalcium phosphate powder 18\%; 3- DP20: Dicalcium phosphate powder 20\%; 4- DM18: Dicalcium microgranulated phosphate $18 \%$; 5MM20: Monodicalcium microgranulated phosphate 20\%; T6- MM21: Monodicalcium microgranulated phosphate $21 \%$, with six repetitions per treatment and one animal per experimental unit, being the initial weight employed as blocking factor.

The animals were disposed, isolately, in metabolism cages in which remained by 12 days, being seven days of adaptation to the cages, diet and metabolic intake normalization and five days to collection of feces and urine.

The minimum $\left(22 \pm 2.99^{\circ} \mathrm{C}\right)$ and maximum $\left(27 \pm 2.01^{\circ} \mathrm{C}\right)$ temperatures of the metabolism room were obtained by the maximum and minimum analogue thermometer, which was disposed in the center of the metabolism room in height corresponding to the animals.

A basic diet was elaborated to be suitable to the nutritional requirements of swines, in agreement with the suggestions of Rostagno et al. (2017) (Table 1), except for calcium $(0.06 \%)$ and the sources evaluated substituted the basic diet, in varying amounts, in a such way to furnish $0.45 \%$ of total $\mathrm{Ca}$ (Table 2).

It was evaluated simultaneously two methods of feces collection: total collection and fecal indicator. To each experimental diet, it was added $1 \%$ of Acid Insoluble Ash - AIA (Celite ${ }^{\mathrm{TM}}$ ), used as fecal indicator. The quantity of feed furnished in the collection period was determined as function of intake in the adaptation phase, which was adjusted by the metabolic weight of the animals $\left(\mathrm{PV}^{0.75}\right)$ (SAKOMURA \& ROSTAGNO, 2007), in two daily meals, at 08:00 a.m. and 16:00 hours, and the water was supplied at will.

The calcium sources were obtained in comercial places in Minas Gerais state and they were sent to physical and chemical analyses (Table 3).

Excreted faeces were collected twice in the day, being determined weight and, subsequently, packed in plastic bags and disposed in freezer $\left(-18^{\circ} \mathrm{C}\right)$ until the final of the collection period, when were thawed at room temperature and homogenized. In this moment, two samples were weighed and dried in a forced ventilation oven at $55^{\circ} \mathrm{C}$. The samples were then ground and stored for analysis. The urine that was excreted during 24 hours had its volume determined and an aliquot of $20 \%$ was packed in glass containers and stored in a refrigerator $\left(3^{\circ} \mathrm{C}\right)$ until the final of the collection period, when were homogenized and an aliquot of $20 \%$ was taken and conserved in refrigerator to analysis. In buckets for urine collection, it was added $20 \mathrm{~mL}$ of a hydrochloric acid $(\mathrm{HCl})$ 1:1 to avoid bacteria proliferation.

It was evaluated the dry matter intake (DMI), total calcium, calcium of test 
food, calcium level of diet, feces, urine, calcium excretion and indigestibility factor. The data were obtained to determine the coefficients of apparent and true digestibility of calcium from the evaluated sources (SAKOMURA \& ROSTAGNO, 2007).

Table 1. Centesimal and calculated composition of the basic $\operatorname{diet}^{1}$

\begin{tabular}{|c|c|}
\hline Ingredients & Basic diet $(\%)$ \\
\hline Corn $(7.88 \%)$ & 68.798 \\
\hline Soybean meal $45 \%$ & 15.904 \\
\hline Corn gluten $60 \%$ & 6.000 \\
\hline Sugar & 3.000 \\
\hline Starch & 3.000 \\
\hline Acid-insoluble ash (AIA) - Celite ${ }^{\mathrm{TM}}$ & 1.000 \\
\hline Soybean oil & 1.000 \\
\hline L-lysine & 0.449 \\
\hline L-threonine & 0.071 \\
\hline DL-methionine & 0.029 \\
\hline L- Tryptophan & 0.029 \\
\hline Salt & 0.409 \\
\hline Mineral mix ${ }^{1}$ & 0.100 \\
\hline Vitamin $\operatorname{mix}^{2}$ & 0.100 \\
\hline Choline chloride & 0.100 \\
\hline BHT & 0.100 \\
\hline Total & 100 \\
\hline \multicolumn{2}{|l|}{ Calculated composition } \\
\hline Calcium (\%) & 0.060 \\
\hline Metabolizable Energy, $\mathrm{kcal} \mathrm{kg}^{-1}$ & 3,348 \\
\hline Total phosphorus $(\%)$ & 0.289 \\
\hline Digestible lysine (\%) & 0.927 \\
\hline Digestible met. + cys. (\%) & 0.547 \\
\hline Digestible Methionine (\%) & 0.291 \\
\hline Crude protein $(\%)$ & 16.820 \\
\hline
\end{tabular}

${ }^{\mathrm{T}}$ Composition per kg: vit. A - 9,000,000 IU; vit. D3 - 1,500,000 IU; vit. E - 10,000 IU; vit. B1, 2g; vit. B2, 5g; vit. B6 - 30g; pantothenic acid - 25g; vit. K3 - 4g; vit. B12 - 40mg; nicotinic acid - 40g; antioxidant $30 \mathrm{~g}$; selenium - 23mg; excipient q.s. - 1,000g.

${ }^{2}$ Composition per kg: $\mathrm{Fe}-180 \mathrm{~g}$; Cu - 20g; Co - 4g; $\mathrm{Mn}-80 \mathrm{~g} ; \mathrm{Zn}-140 \mathrm{~g}$; I $4 \mathrm{~g}$; excipient q.s. - 1,000g.

Table 2. Percentual of substitution of the basic diet for supplement

\begin{tabular}{lccc}
\hline Sources & Source substitution $^{2}$ & Ca experimental diet $^{3}$ & Ca experimental diet $^{4}$ \\
\hline CAC & 1.034 & 0.45 & 0.45 \\
DP18 & 1.875 & 0.45 & 0.44 \\
DP20 & 1.652 & 0.45 & 0.46 \\
DM18 & 1.848 & 0.45 & 0.45 \\
MM20 & 2.119 & 0.45 & 0.45 \\
MM21 & 2.600 & 0.45 & 0.48 \\
\hline
\end{tabular}

${ }^{\mathrm{I}}$ Calcium sources: $\mathrm{CAC}=$ Calcitic limestone; DP18 $=$ Dicalcium phosphate powder $18 \%$; DP20 $=$ Dicalcium phosphate powder 20\%; DM18: Dicalcium microgranulated phosphate 18\%; MM20 = Monodicalcium microgranulated phosphate $20 \%$; MM21 = Monodicalcium microgranulated phosphate $21 \%$.

${ }^{2}$ Substitution of supplement in the natural matter $(\mathrm{Kg})$.

${ }^{3}$ Calculated value $(\%)$.

${ }^{4}$ Value analyzed in the Laboratory of Animal Nutrition - DZO - UFV (\%). 
Table 3. Composition and relation between minerals of the experimental treatments

\begin{tabular}{|c|c|c|c|c|}
\hline \multirow[b]{2}{*}{ Calcium sources ${ }^{1}$} & \multicolumn{2}{|c|}{ Physical composition $^{2}$} & \multicolumn{2}{|c|}{ Chemical composition $^{2}$} \\
\hline & Granulometry & $\begin{array}{l}\text { Solubility of the P } \\
\text { in } \mathrm{H}_{2} \mathrm{O}(\%)\end{array}$ & P (\%) & $\mathrm{Ca}(\%)$ \\
\hline CAC & Powder & - & - & 37.7 \\
\hline DP18 & Powder & 8 & 18.3 & 20.8 \\
\hline DP20 & Powder & 4 & 19.9 & 23.6 \\
\hline DM18 & Microgranulated & 15 & 18.1 & 21.1 \\
\hline MM20 & Microgranulated & 45 & 20.0 & 18.4 \\
\hline MM21 & Microgranulated & 75 & 21.0 & 15.0 \\
\hline
\end{tabular}

${ }^{\mathrm{T}}$ Calcium sources: $\mathrm{CAC}=$ Calcitic limestone; DP18 $=$ Dicalcium phosphate powder $18 \%$; DP20 = Dicalcium phosphate powder 20\%; DM18 = Dicalcium microgranulated phosphate $18 \%$; MM20 = Monodicalcium microgranulated phosphate 20\%; MM21 = Monodicalcium microgranulated phosphate $21 \%$.

${ }^{2}$ Analyses conducted at the laboratory of Rodes Química Cajati LTDA in Cajati/SP.

Table 4. Distribution of particle size and geometric mean diameter (GMD) of the calcium sources ${ }^{1}$

\begin{tabular}{lcccccc}
\hline \multirow{2}{*}{ Sieve number - diameter } & \multirow{2}{*}{ Unit } & \multicolumn{5}{c}{ Tested Phosphates } \\
\cline { 3 - 7 } & & DP18 & DP20 & DM18 & MM20 & MM21 \\
\hline$\# 09-2.00 \mathrm{~mm}$ & \% retained & 0.07 & 0.02 & 0 & 0 & 0 \\
$\# 12-1.41 \mathrm{~mm}$ & \% retained & 0.61 & 0.34 & 3.60 & 4.80 & 1.37 \\
$\# 20-0.84 \mathrm{~mm}$ & \% retained & 2.17 & 3.18 & 17.50 & 22.10 & 30.10 \\
$\# 35-0.50 \mathrm{~mm}$ & \% retained & 5.40 & 10.30 & 30.30 & 26.90 & 54.50 \\
$\# 60-0.25 \mathrm{~mm}$ & \% retained & 8.70 & 13.10 & 17.20 & 17.50 & 11.30 \\
$\# 100-0.15 \mathrm{~mm}$ & \% retained & 12.00 & 14.70 & 8.30 & 13.00 & 1.79 \\
GMD & $\mu \mathrm{m}$ & 415.07 & 438.33 & 767.51 & 756.08 & 944.68 \\
\hline
\end{tabular}

${ }^{\mathrm{I}}$ Calcium sources: $\mathrm{CAC}=$ Calcitic limestone; DP18 $=$ Dicalcium phosphate powder $18 \%$; DP20 $=$ Dicalcium phosphate powder $20 \%$; DM18 = Dicalcium microgranulated phosphate $18 \%$; MM20 = Monodicalcium microgranulated phosphate $20 \%$; MM21 = Monodicalcium microgranulated phosphate $21 \%$.

The bromatological composition of the experimental rations as well as the opening of the samples of diets, feces and urine to the achievement of the mineral solution were realized according with the methodologies described by AOAC (2007) and the analysis of Acid Insoluble Ash - AIA, it was realized by digestion with hydrochloric acid (4N), following the procedures of Kavanagh et al. (2001), in the Laboratory of Animal Nutrition (LANA) of UFV. The mineral solutions obtained by nitroperchloric digestion (4:1) were submitted to the detection in the Atomic Absorption Spectrometer (Varian, SpectrAA 250 PLUS, Texas) in order to obtain the concentration of the total calcium of the samples.

The values of the true digestibility were estimated by the correction of the endogenous loses of the diets. It was utilized the value of $0.541 \mathrm{~g}$ endogenous $\mathrm{Ca} / \mathrm{kg}$ of dry matter (DM) ingested, in agreement with Salguero Cruz et al. (2014).

The normality of the experimental errors between the treatments of the variables was evaluated previously, using the tests of Shapiro-Wilk. The 
effects of the calcium sources and the collection methodologies upon the dependent variables were verified by variance analysis. The tests of Tukey and Dunett were applied to comparison of the averages with $5 \%$ of significance.

\section{RESULTS AND DISCUSSION}

There was no difference between the sources for the parameters related to calcium balance $(\mathrm{P}>0.05)$ (Table 5).

Table 5. Parameters related to the metabolic balance of calcium from different sources

\begin{tabular}{lccccccc}
\hline Parameter & $\mathrm{CAC}^{1}$ & $\mathrm{DP}^{1} 8^{1}$ & $\mathrm{DP}^{1} 0^{1}$ & $\mathrm{DM}^{1} 8^{1}$ & $\mathrm{MM} 20^{1}$ & $\mathrm{MM}^{1} 1^{1}$ & $\mathrm{CV}^{2}$ \\
\hline Ca intake $(\mathrm{g} /$ per) & 19.58 & 18.48 & 19.97 & 18.35 & 20.96 & 18.34 & 15.48 \\
Ca feces $(\mathrm{g} / \mathrm{per})$ & 6.09 & 6.79 & 5.71 & 5.89 & 6.50 & 5.23 & 26.15 \\
Ca urine $(\mathrm{g} /$ per) & 0.015 & 0.007 & 0.003 & 0.002 & 0.024 & 0.010 & 90.29 \\
Ca endogenous (g/per) & 2.16 & 2.10 & 2.20 & 2.00 & 2.39 & 2.10 & 15.42 \\
Ca retained $(\mathrm{g} /$ per) & 12.81 & 11.55 & 13.80 & 12.66 & 14.04 & 12.63 & 14.58 \\
Ca retained \% & 64.58 & 62.92 & 68.29 & 69.03 & 66.10 & 69.03 & 7.56 \\
\hline
\end{tabular}

${ }^{1}$ Calcium sources: $\mathrm{CAC}=$ Calcitic limestone; $\mathrm{DP} 18=$ Dicalcium phosphate powder $18 \%$; DP20 $=$ Dicalcium phosphate powder $20 \%$; DM18 $=$ Dicalcium microgranulated phosphate $18 \%$; MM20 = Monodicalcium microgranulated phosphate $20 \%$; MM21 = Monodicalcium microgranulated phosphate $21 \%$.

${ }^{2} \mathrm{CV}=$ Coefficient of variation (\%).

${ }^{3}(\mathrm{~g} / \mathrm{per})=$ grams in the collection period.

The difference in the granulometry of the sources did not influence the calcium intake, being proportional to the feed consumption. As for the calcium concentration in the faeces, the results showed that, on average, $30 \%$ of the ingested mineral was excreted. This fact occurred when the pigs received diet treated with exogenous phytase, which constitutes a factor that may have contributed to the lower calcium excretion that was observed in the cited studies. Likewise, Kiefer et al. (2012), working with the addition of phytase in the diet of pigs to evaluate the nutrient digestibility under thermoneutral conditions, found fecal calcium excretion of $2.70 \%$ lower than the value encountered in the present study.

In urine, there was low calcium excretion. Similarly to this work, Salguero Cruz et al. (2014) did not obtain calcium values in urine samples analyzed. According to Sakomura \& Rostagno (2007), the excretion of some minerals through urine, such as calcium, is very reduced, being more expressive in feces, which is the main form of excretion of this mineral. Analyzes were performed to obtain reference values, since data on calcium content in the urine are scarce. From this information, it is possible to suggest that calcium sources were not supplied above the amount supported by the calcium transport system.

According to Bindels et al. (2011), approximately $98 \%$ of the filtered calcium is reabsorbed throughout the nephron in mammals and this is regulated mainly by vitamin $\mathrm{D}$ and parathyroid hormone. Benson et al. (1969) reported that animals respond to an adaptive mechanism based on calcium intake. That is, when consumption is low, the animal has the capacity to increase the retention of this mineral, activating the systems of transcellular absorption in the intestine and reabsorption in the kidneys, which 
may explain the minimum values of calcium found in urine.

The coefficients of apparent and true digestibilities, determined from the total collection, were not influenced by the calcium sources $(\mathrm{P}>0.05)$ (Table 6).
The Dunett test was applied to verify the contrasts of the mean values of each phosphate in relation to the control (calcitic limestone) and this test also did not show difference $(\mathrm{P}>0.05)$.

Table 6. Coefficients of apparent fecal digestibility (CAD) and true fecal digestibility (CTD) by the methods of total collection and fecal indicator

\begin{tabular}{|c|c|c|c|c|c|c|}
\hline \multirow[b]{2}{*}{ Calcium sources ${ }^{1}$} & \multicolumn{2}{|c|}{ CAD $(\%)^{2}$} & \multirow[b]{2}{*}{ Mean } & \multicolumn{2}{|c|}{ CTD $(\%)^{2}$} & \multirow[b]{2}{*}{ Mean } \\
\hline & $\begin{array}{c}\text { Total } \\
\text { collection }\end{array}$ & $\begin{array}{c}\text { Fecal } \\
\text { indicator }\end{array}$ & & $\begin{array}{c}\text { Total } \\
\text { collection }\end{array}$ & $\begin{array}{c}\text { Fecal } \\
\text { indicator }\end{array}$ & \\
\hline $\mathrm{CAC}$ & $76.01^{\mathrm{B}}$ & $83.76^{\text {Aab }}$ & 79.88 & 81.89 & $83.06^{\mathrm{ab}}$ & 82.47 \\
\hline DP18 & $71.57^{\mathrm{B}}$ & $79.61^{\text {Aab }}$ & 75.59 & 77.52 & $84.22^{\mathrm{ab}}$ & 80.87 \\
\hline DP20 & $79.14^{\mathrm{B}}$ & $83.48^{\mathrm{Aab}}$ & 81.31 & 85.08 & $86.23^{\mathrm{ab}}$ & 85.65 \\
\hline DM18 & $74.91^{\mathrm{B}}$ & $77.24^{\mathrm{Ab}}$ & 76.07 & 80.89 & $82.42^{\mathrm{b}}$ & 81.65 \\
\hline MM20 & $77.54^{\mathrm{B}}$ & $81.30 \mathrm{~A}^{\mathrm{ab}}$ & 79.42 & 83.52 & $84.78^{\mathrm{ab}}$ & 84.15 \\
\hline MM21 & $80.80^{\mathrm{B}}$ & $85.88^{\mathrm{Aa}}$ & 83.34 & 86.85 & $89.86^{\mathrm{a}}$ & 88.35 \\
\hline $\mathrm{CV}^{3}$ & 7.81 & 4.45 & - & 7.24 & 3.55 & - \\
\hline \multicolumn{7}{|c|}{$\begin{array}{l}{ }^{1} \text { Calcium sources: } \mathrm{CAC}=\text { Calcitic limestone; DP18 }=\text { Dicalcium phosphate powder } 18 \% \text {; DP20 }= \\
\text { Dicalcium phosphate powder } 20 \% \text {; DM18 = Dicalcium microgranulated phosphate } 18 \% \text {; MM20 }= \\
\text { Monodicalcium microgranulated phosphate } 20 \% \text {; MM } 21=\text { Monodicalcium microgranulated } \\
\text { phosphate } 21 \% \text {. } \\
{ }^{2} \text { Averages followed by different lower-case letters in the column and different capital letters in the row } \\
\text { differ from each other by the Tukey test at } 5 \% \text {. } \\
{ }^{3} \mathrm{CV}=\text { Coefficient of variation }(\%) \text {. }\end{array}$} \\
\hline
\end{tabular}

However, it was observed difference (P $<0.05)$ between the calcium sources for the ccoefficients of apparent and true digestibility by the indirect method (use of fecal indicator). Higher apparent and true digestibility coefficients for calcium were obtained for the animals that consumed the diets containing microgranulated phosphate with $21 \%$ of phosphorus (MM21). The diets called CAC, DP18, DP20 and MM20 obtained intermediate values and the DM18 treatment generated the lowest value (P $<0.05$ ) observed in the present work.

The difference in grain size may have interfered in the digestibility results of calcium, since microgranulated phosphate with $21 \%$ of phosphorus (MM21) had the highest GMD (944.68 $\mu \mathrm{m})$. Authors, such as Griffith \&
Schexnailder (1970), believe that the calcium is more available when the feed present larger particles, which is caused by the greater retention of the food in the upper part of the gastrointestinal tract (GIT). This retention would allow a longer period of stay in the acidic environment, leading to a greater solubilization of the food. This explanation may explain the best digestibility of calcium from this source (MM21).

The higher calcium absorption related to MM21 could be caused as function of the higher solubilization of the respective phosphate source in the stomach compartment. This fact is related to the $\mathrm{pKa}$ values of the monocalcium phosphates. Considering that these compounds are salts 
originated from a weak acid, which is phosphoric acid $\left(\mathrm{H}_{3} \mathrm{PO}_{4}\right)$, with $\mathrm{pKa}$ values of approximately 2.2, 7.1 and 12.4 , it is possible to infer that this species would not be triply ionized in physiological $\mathrm{pH}$ conditions, meaning that the most abundant species in the physiological medium would be $\mathrm{H}_{2} \mathrm{PO}^{4-}$ and $\mathrm{HPO}_{4}{ }^{2-}$ (TEIXEIRA et al., 2016).

These anions as well as the calcium divalent cation $\left(\mathrm{Ca}^{2+}\right)$, which is originated from the dissociation of the respective phosphates, are encountered in significant concentration at $\mathrm{pH}$ values found in the gastrointestinal tract (GIT). Depending of the other constituents of the swine diet, this calcium divalent cation can generate several other types of chemical interaction, which can produce small soluble salts and coordination compounds, including chelated compounds with biological macromolecules, such as proteins, lipids and macromolecular carbohydrates.

Ammerman et al. (1995) reported in its work that particle size is a determinant factor in the availability of calcium and phosphorus in the defluorinated phosphates, since the solubility of a phosphate increases as it reduces the particle size of the food. However, work published by Araújo et al. (2010) showed that particle size did not influence the variables of laying rate, feed conversion, egg weight, egg mass, percentage and shell thickness, and egg specific gravity of commercial laying hens, indicating that the availability of calcium and phosphorus was not influenced by the granulometry of the food.

There was a difference between the direct and indirect methods only for the apparent digestibility coefficients of the calcium sources $(P<0.05)$. For the true digestibility coefficients, the methods did not influence the results $(\mathrm{P}>0.05)$. The difference between the methods can be explained by the faecal recovery of the animals that consumed the celite diet. It is not uncommon for CIA use to overestimate the digestibility coefficients. This fact may have occurred due to the incomplete solubilization of $\mathrm{HCl}$-soluble minerals, such as calcium and phosphorus in feces, overestimating CIA content as reported by (LEÃO et al., 2008; ZANATTA et al., 2013). Bünzen et al. (2009) compared the total collection and fecal indicator methods and did not verify differences between them for the coefficients of apparent and true digestibility of the phosphorus. Rocha Junior et al. (2015) and Santana et al. (2017), in a study with swines, did not found any difference between the total collection and the faecal indicator methodologies.

The results suggest that both methods can be used to determine the true digestibility of calcium. Salguero Cruz et al. (2014), working with diets containing different sources of calcium and evaluating the two methods of collection, also did not observe interaction between the factors. Considering that the objective of this work is focused on different collection methods in order to evaluate the similarity between the methods to replace the traditional one (total collection), the results of the present work must contribute significantly with the literature. The indirect methods proposed for estimation of fecal excretion and digestibility, such as the use of indicators, have presented advantages over total excreta collection, due to the simplicity and convenience of its use.

Acid insoluble ash (AIA) is a naturally indigestible compound, and, therefore, is considered as an internal indicator. However, the content of AIA in grains is low and the amount supplied in the diets is not enough to act as an 
indicator. Thus, eventually, external sources of AIA (Celite TM, sand and silica) can be added to diets to improve the accuracy of estimates, being also considered as external indicator, as assessed by Salguero Cruz et al. (2014), Rocha Junior et al. (2015) and Santana et al. (2017).

Carvalho et al. (2013) compared different methods of analysis of acidinsoluble ash with the total collection method to the determination of metabolizable energy of corn to birds. One of the methods of AIA analysis studied by the authors is similar to the one used in this work. These authors verified that the stool index recovery rate was approximately $100 \%$ and concluded that AIA can be used as an indicator of metabolizable energy instead of total collection.
Salguero Cruz et al. (2014), working with diets containing $0.37 \%$ of total calcium, found no difference between calcium sources nor interference of fecal collection methods in the calcium digestibility. The true calcium digestibility coefficient obtained by the authors for calcitic limestone was $79.36 \%$, when it was applied the total collection method; and the respective value was $84.55 \%$ when it was employed the fecal indicator method, which are similar data to those determined in the present experiment, with difference of $+2.53 \%$ for total collection and $-1.49 \%$ for the fecal indicator method.

The true digestible calcium values of the sources (Table 7) were calculated from the true digestibility coefficients estimated in this study for castrated pigs in the growth phase.

Table 7. Total digestible calcium content of the studied sources

\begin{tabular}{lccc}
\hline \multirow{2}{*}{ Calcium sources } & \multirow{2}{*}{ Total calcium $(\%)^{2}$} & \multicolumn{2}{c}{ Digestible calcium (\%) } \\
\cline { 3 - 4 } & 37.70 & 30.87 & Total collection \\
\hline CAC & 20.80 & 16.12 & 31.31 \\
DP18 & 23.60 & 2.08 & 17.52 \\
DP20 & 21.10 & 17.07 & 20.35 \\
DM18 & 18.40 & 15.37 & 17.39 \\
MM20 & 15.00 & 13.03 & 15.60 \\
MM21 & &
\end{tabular}

${ }^{1}$ Calcium sources: $\quad$ CAC $=$ Calcitic limestone; DP18 = Dicalcium phosphate powder 18\%; DP20 = Dicalcium phosphate powder 20\%; DM18 = Dicalcium microgranulated phosphate 18\%; MM20 = Monodicalcium microgranulated phosphate $20 \%$; MM21 = Monodicalcium microgranulated phosphate $21 \%$.

${ }^{2}$ Analyzed values.

Salguero Cruz et al. (2014) calculated the values of digestible calcium for growing pigs and reported $31.58 \%$ for calcitic limestone. This value is a very similar data to that obtained in present study, which is $31.31 \%$.

The mineral supplementation of monogastric diets, either with organic or inorganic products, would present a best performace if the feed formulations would be based on the digestible calcium content and not only on the total calcium content. However, this is still a reality. In any case, with the advancement of research, the trend is that in near future, this reality will be modified. 
Calcium intake and its apparent and true digestibilities, evaluated by the total collection method, were not influenced by the calcium sources supplied to the swines. The faecal indicator method, through the use of acid insoluble ash, furnished better average digestibility coefficients, showing more sensitivity, but did not present the same difference to the true digestibility coefficient. The microgranulated phosphate with $15 \%$ of total calcium and GMD of $944.68 \mu \mathrm{m}$ generated higher apparent and true digestibility coefficients, which constituted a result that was encountered only in the evaluation through the indirect collection method. In this way, the fecal indicator method could be employed to determine calcium digestibility in substitution to the total collection method. In any case, it is important to notice that it would be interesting that a higher effort in terms of research can be performed upon this topic, considering its high relevance with respect to the swine nutrition.

The total collection method and the faecal indicator method did not affect the true digestibility coefficient of calcium, permitting to infer that these two methodologies can be employed to determine the calcium digestibility.

The calcium digestibility of the microgranulated dicalcium phosphate $21 \%$ (MM21) was superior in comparison with the other calcium sources evaluated in the present work.

The average values of true digestibility of the calcium sources, in percentage, are: calcitic limestone: 82.47 ; dicalcium phosphate powder 18\%: 80.87; dicalcium phosphate powder 20\%: 85.65; dicalcium microgranulated phosphate $18 \%$ : 81.65 ; monodicalcium microgranulated phosphate $20 \%$ : 84.15 ; and monodicalcium microgranulated phosphate 21\%: 88.35. The two methodologies can be used to determine the digestibility of calcium.

\section{REFERENCES}

AMMERMAN, C.B.; BAKER, D.H.; LEWIS, A.J. Bioavailability of nutrients for animals: amino acids, minerals and vitamins. San Diego: Academic Press, 1995. 118p.

ARAÚJO, L.F.; JUNQUEIRA, O.M.; ARAÚJO, C.S.S.; SAVIETTO, D.; ALBUQUERQUE, R.; BARBOSA, L.C.G.S. Níveis de fósforo disponível e tamanho de partícula do fosfato bicálcico na dieta de poedeiras comerciais de 24 a 58 semanas de idade. Revista Brasileira de Zootecnia, v.39, n.6, p.1223-1227, 2010.

ARAÚJO, J.A.; SILVA, J.H.V.; AMÂNCIO, A.L.L.; LIMA, C.B.; OLIVEIRA, E.R.A. Fontes de minerais para poedeiras. Acta Veterinaria Brasilica, v.2, n.3, p.53-60, 2008.

ASSOCIATION OF OFFICIAL ANALYTICAL CHEMISTS - AOAC. Official Methods of Analysis. 18th ed. rev. Gaithersburg, MD, 2007.

BENSON, J.D.; EMERY, R.S.; THOMAS, J.W. Effects of previous calcium intakes on adaptation to low and high calcium diets in rats. Journal Nutrition, v.97, p.53-60, 1969.

BINDELS, R.J.M.; HOENDEROP, J.G.J.; BIBER, J. Transporte de cálcio, magnésio e fosfato. In: BRENNER, B.M. (Ed.). O rim. 9.ed. Filadélfia, PA: Elsevier Saunders; 2011. p.226-251. 
BÜNZEN. S.; ROSTAGNO, H.S.; LOPES, D.C.; GOMES, P.C.; HASHIMOTO, F.A.M.; APOLÔNIO, L.R.; BORSATTO, C.G.

Digestibilidade aparente e verdadeira do fósforo de alimentos de origem animal para suínos. Arquivo Brasileiro de Medicina Veterinária e Zootecnia, v.61, p.903-909, 2009.

CARVALHO, G.B.; DOURADO, L.R.B.; LOPES, J.B.; FERREIRA, A.H.C.; RIBEIRO, M.N.; SILVA, S.R.G.; MERVAL, R.R.; BIAGIOTTI, D.; SILVA, F.E.S. Métodos de análise da cinza insolúvel em ácido utilizada como indicador na determinação da energia metabolizável do milho para aves. Revista Brasileira de Saúde e Produção Animal [online], v.14, p.43-53, 2013.

FIORINI, L.S. Dossiê: Os minerais na alimentação. Revista Food Ingredients Brasil, v.4, p.48-59, 2008.

GRIFFITH, G.; SCHEXNAILDER, R. The relation of dietary particle size to phosphorus availability in purified diets. Poultry Science, v.49, p.1271-1274, 1970.

KAVANAGH, S.; LYNCH, P.B.; MARA, O.F.; CAFREY, P.J. A comparison of total collection and marker technique for the measurement of apparent digestibility of diets for growing pigs. Animal Feed Science and Technology, v.89, p.49-58, 2001.

KIEFER, C.; SANTOS, T.M.B.; MOURA, M.S.; SILVA, C.M.; LUCAS, L.S.; ROSA, E.M.

Digestibilidade de dietas suplementadas com fitase para suínos sob diferentes ambientes térmicos. Ciência Rural, v.42, p.1483-1489, 2012.
LEÃO, V.P.C.; FERREIRA, J.Q.;

FIGUEIREDO, M.P.; VIANA, A.E.S.; PEREIRA, L.G.R. Cinza insolúvel em ácido em ensaio de digestibilidade em ovinos alimentados com cana-de-açúcar e feno da parte aérea da mandioca.

Revista Brasileira de Saúde e Produção Animal [online], v. 9, p.480487, 2008.

ROCHA JUNIOR, C.M.; TEIXEIRA, A.O.; HANNAS, M.I.; SANTANA, A.L.A.; CARVALHO, T.A.; OLIVEIRA, B.L.; MOREIRA, L.M.; BRIGHENTI, C.R.G. Digestibility of phosphorus in powder and microgranular phosphate in diets for pigs. Revista Brasileira de Saúde e Produção Animal [online], v.16, p.544-577, 2015.

ROSTAGNO, H.S.; ALBINO, L.F.T.; HANNAS, M.I. Tabelas brasileiras para aves e suínos. Viçosa, MG: UFV, 2017. 252p.

SAKOMURA, N., ROSTAGNO, H.S. Métodos de pesquisa em nutrição de monogástricos. Jaboticabal, SP: FUNEP, 2007.283p.

SALGUERO CRUZ, S.C.; ROSTAGNO, H.S.; HANNAS, M.I.; CARVALHO, T.A.; MAIA, R.C.; PESSOA, G.B.S.

Digestibilidade do cálcio de ingredientes para suínos, avaliada por meio de dois Métodos. Arquivo Brasileiro de Medicina Veterinária e Zootecnia, v.66, p.1539-1546, 2014.

SANTANA, A.L.A.; CARVALHO, P.L.; OLIVEIRA, N.T.E.; GONÇALVES JUNIOR, A.C.; GAZOLA, A.P.; CASTRO, D.E.S.; CARVALHO, S.T.; OLIVEIRA, A.C. Different sources of calcium for starter pig diets. Livestock Science, v.206, p. 175-181, 2017. 
SELLE, P.H.; COWIESON, A.J.;

RAVINDRAN, V. Consequences of calcium interactions with phytate and phytase for poultry and pigs. Livestock Science, v.124, p.126-141, 2009.

TEIXEIRA, A.O.; CORASSA, A.; MOREIRA, L.M.; NOGUEIRA, E.T.; LOPES, J.B.; ROCHA JUNIOR, C.M.; FERREIRA, V.P.A. Bone characteristics of pigs fed with different phosphorus sources. Revista Colombiana de Ciencias Pecuarias, v.29, p.245-254, 2016.

ZANATTA, C.P.; GABELONI, L.R.; FÉLIX, A.P.; BRITO, C.B.M.;

OLIVEIRA, S.G.; MAIORKA, A.

Metodologias para determinação da digestibilidade de dietas contendo fontes proteicas vegetal ou animal em cães.

Ciência Rural, v.43, p.696-701, 2013.

Receipt date: $18 / 12 / 2017$

Approval date: 21/02/2018 